\title{
Binding Events of $(S)$ - $N$-(3-Oxo-octanoyl)-homoserine Lactone with Agrobacterium tumefaciens Mutant Cells Studied by Saturation Transfer Difference NMR
}

\author{
Luís Fernando Cabeça, Armando Mateus Pomini, Pedro Luiz, R. Cruz and \\ Anita J. Marsaioli*
}

Chemistry Institute, University of Campinas, PO Box 6154, 13083-970 Campinas-SP, Brazil

\begin{abstract}
Quorum-sensing é um fenômeno de comunicação amplamente estudado em bactérias, o qual envolve a produção e detecção de substâncias sinalizadoras que dependem do comportamento da colônia e da densidade celular. No presente trabalho, a interação entre a substância sinalizadora (S)-N-(3-oxo-octanoil)-HSL e a membrana celular da A. tumefaciens NTL4(pZLR4) foi estudada utilizando a espectroscopia de RMN da diferença de transferência de saturação (STD-NMR). O mapa do epitopo da substância foi obtido, mostrando que a cadeia hidrofóbica acila apresentou o mais importante ponto de interação. Os resultados foram interpretados em comparação a um sistema modelo de membrana, os lipossomas. Também foi analisado o uso da $\beta$-ciclodextrina como carreador da acil-HSL.
\end{abstract}

Quorum-sensing is a widely studied communication phenomenon in bacteria, which involves the production and detection of signaling substances in relation with cell density and colony behavior. Herein, the membrane binding interactions of the signal ( $S$ )- $N$-(3-oxo-octanoyl)-HSL with $A$. tumefaciens NTL4(pZLR4) cells were studied using saturation transfer difference NMR spectroscopy (STD-NMR). The substance epitope map was obtained showing that the hydrophobic acyl chain is the most important interacting site for the signal and the cell membrane. Results were interpreted upon comparisons with a simpler system, using liposomes as membrane models. Some insights on the use of $\beta$-cyclodextrin as acyl-HSL carrier were also provided.

Keywords: STD-NMR, acyl-homoserine lactone, membrane interactions

\section{Introduction}

It is well recognized nowadays that bacteria use quorum-sensing communication circuits to regulate a wide array of physiological activities. These processes include symbiosis, virulence, competence, conjugation, antibiotic production, motility, sporulation and biofilm formation, among several other phenotypes crucial for bacterial survival and host infection. This phenomenon relies on the production of low molar mass signaling molecules usually related to cell density. In many Gram-negative bacteria the acyl-homoserine lactones (acyl-HSLs) are the most studied chemical signals. ${ }^{1}$

In the quorum-sensing process, synthases (LuxI homologs) produce the signaling molecules, which diffuse from the cytoplasm to the near environment through the cellular membrane in the case of short chain acyl-HSLs or through active efflux pumping in long chain ones. ${ }^{2}$

*e-mail: anita@iqm.unicamp.br
The acyl-HSL concentration is related to cell density, i.e., as the colony grows the metabolite concentration also increases due to the presence of new producing individuals. The process continues until a threshold concentration is reached, when the metabolites bind to transcriptional proteins (LuxR homologs) and the complex regulates gene expression. ${ }^{3}$ Therefore, quorum-sensing allows whole bacterial populations to act coordinately, improving their chances of successful environment colonization.

One of the most interesting quorum-sensing mechanisms was reported for Agrobacterium tumefaciens, a phytopathogen that induces crown gall tumors in plants via the transfer of oncogenic DNA to the nucleus of its host. It employs a complex regulatory mechanism to control plasmid conjugation transfer, using ( $S$ )- $N$-(3-oxo-octanoyl)-HSL (1) as the main self-produced signaling substance. ${ }^{4}$ In a proposed model, substance $\mathbf{1}$ binds to the monomeric TraR receptor protein, which is compartmentalized within the membrane from where it can only interact with external 1 molecules that enter into the cells through membrane 
diffusion. This interaction causes TraR monomers to dimerise thereby masking the hydrophobic region of these proteins and allowing them to enter the cytoplasm and interact with specific DNA promoters and then coordinate phenotype expression, including the transfer of oncogenic Ti plasmid. ${ }^{5}$

The mutant A. tumefaciens NTL4(pZLR4) was built by Cha and co-workers ${ }^{6}$ and is extensively employed as reporter for acyl-HSLs detection in colorimetric bioassays. Architecture of pZLR4 plasmid includes a traG:lacZ fusion and traR. The traR gene encodes the synthesis of TraR receptor proteins, which can bind to exogenously added 1 molecules creating a complex that activates the transcription of the traG gene, which has been mutated (interrupted) by the insertion of the $l a c Z$ gene, encoding the $\beta$-galactosidase enzyme. Thus, $\beta$-galactosidase enzyme cleaves the $\mathrm{X}$-gal reagent added in colorimetric bioassays, producing a blue-green indigo derivative. ${ }^{6}$ This interesting biological test reveals that there is a cascade of biochemical reactions induced by the interaction of $\mathbf{1}$ with the mutated A. tumefaciens cells, as also observed for Ti oncogenic plasmid transfer in the crown gall disease in wild type strains. ${ }^{5,6}$

The interaction of $\mathbf{1}$ with TraR receptor protein was solved based on X-ray diffraction of a crystallized complex dimer. The study revealed the main anchoring sites of $\mathbf{1}$ with different aminoacid residues and the protein structural changes induced by complexation that increases the complex affinity to specific DNA-binding sites. ${ }^{7}$ However, little is known about the first interactions of the signaling substance with the cells, especially at the membrane level. Radioisotope-labeled acyl-HSLs studies provided evidence that short chain acyl-HSLs (4 carbon acyl side chain) cross the cell membrane through diffusion, while longer ones are captured through active pumping, probably mediated by permeases or carrying proteins. ${ }^{2}$

Therefore, in A. tumefaciens it seems that the quorum sensing phenomenon depends on a primary event consisting of acyl-HSL diffusion through the cell membrane. Up to now, the importance of each molecular moiety of $\mathbf{1}$ for the membrane interactions is not clear.

Based on our recent results in defining the architecture of drug-macromolecule complexes taking liposomes as membrane models, ${ }^{8}$ this paper describes the initial binding events of 1 with the model strain A. tumefaciens NTL4(pZLR4) by saturation transfer difference nuclear magnetic resonance spectroscopy (STD-NMR), identifying the main anchoring sites of $\mathbf{1}$ and the cell membrane. ${ }^{9-11}$ The strain A. tumefaciens NTL4(pZLR4) constitutes an interesting model for (acyl-HSL)-cell binding studies since it is unable to produce acyl-HSLs and the experiments would not have interference from self-produced molecules. ${ }^{6}$
The experimental results with cells were rationalized by comparisons with liposome-based studies, employed as membrane models.

\section{Experimental}

\section{General}

NMR analyses were carried out on Varian INOVA-500 or Bruker Gemini-300 spectrometers, using $\mathrm{CDCl}_{3}$ as solvent and TMS as internal reference for pure synthetic product $\mathbf{1}$ analyses. For STD NMR and ${ }^{1} \mathrm{H}$ nOe NMR experiments, $\mathrm{D}_{2} \mathrm{O}$ and $\left(\mathrm{CD}_{3}\right)_{2} \mathrm{SO}$ were employed as solvents and the residual HDO signal at 4.70 ppm was used as internal reference. A Perkin-Elmer 341 polarimeter equipped with a sodium lamp was employed for $[\alpha]_{D}{ }^{20}$ analysis, using methanol (HPLC grade) as solvent. The IR spectrum was taken with a Bomen Michelson MB spectrophotometer, using a $\mathrm{KBr}$ (Merck) pellet as sample support. Column chromatography purifications were carried out with silica gel (Acros, 0.035$0.070 \mathrm{~mm}$ ) and high quality solvents. All solvents were previously treated with anhydrous sodium sulfate followed by fractionation. The reagents were from Aldrich or Sigma.

\section{GC-MS analyses}

GC-MS analysis (70 eV) was carried out with an Agilent 6890 chromatograph coupled to a Hewlett Packard 5973 mass detector, equipped with a capillary column (HP5, $30 \mathrm{~m} \times 0.25 \mathrm{~mm} \times 0.25 \mu \mathrm{m})$, using a temperature program from 100 to $290{ }^{\circ} \mathrm{C}$ at $10^{\circ} \mathrm{C} \mathrm{min}$ meld at $^{-1}$ and he ${ }^{\circ} \mathrm{C}$ for

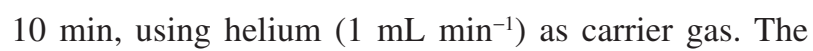
sample $(1 \mu \mathrm{L})$ was injected in the split mode in ethyl acetate $\left(1 \mathrm{mg} \mathrm{mL}^{-1}\right)$, with the injector at $250{ }^{\circ} \mathrm{C}$.

\section{Chiral GC-FID analyses}

GC-FID analysis was conducted with an Agilent 6890 chromatograph using the chiral column Chrompack Chirasil $\mathrm{CD}(25 \mathrm{~m} \times 0.25 \mathrm{~mm} \times 0.25 \mu \mathrm{m})$. Highly pure hydrogen was employed as carrier gas $\left(1 \mathrm{~mL} \mathrm{~min}^{-1}\right)$. The injector and detector temperatures were $220^{\circ} \mathrm{C}$ and $250^{\circ} \mathrm{C}$, respectively. The product $\mathbf{1}$ was dissolved in highly pure ethyl acetate ( $\left.1 \mathrm{mg} \mathrm{mL}^{-1}\right)$ and injected in the split mode $(1 / 100)$. The temperature program was $50-180{ }^{\circ} \mathrm{C}\left(1^{\circ} \mathrm{C} \mathrm{min}{ }^{-1}\right)$ held for $40 \mathrm{~min}$ at $180{ }^{\circ} \mathrm{C}$.

\section{STD NMR spectroscopy}

NMR experiments were performed on a Varian INOVA-500 spectrometer operating at $11.74 \mathrm{~T}$, observing 
${ }^{1} \mathrm{H}$ at $499.89 \mathrm{MHz}$. The spectrometer was equipped with a $5 \mathrm{~mm}$ triple resonance $\left({ }^{15} \mathrm{~N},{ }^{13} \mathrm{C},{ }^{1} \mathrm{H}\right)$ inverse detection probe with z-gradient. STD experiments used selective saturation at $-0.5 \mathrm{ppm}$ using Gaussian train pulses for the on-resonance and at $30 \mathrm{ppm}$ for the STD-control. Selective presaturation of the residual water signal of $\mathrm{D}_{2} \mathrm{O}$ in the liposomes and A. tumefaciens experiments was achieved by a train of Gaussian-shaped pulses of $50 \mathrm{~ms}$ each, separated by a $1 \mathrm{~ms}$ delay. The 50 selective pulses in the saturation period lead to $2.55 \mathrm{~s}$ of total length of the saturation train. The total number of scans was 512 or 1024, 16 dummy scans were applied. Spectral widths of 12 ppm were typically used for the 1D STD NMR spectra.

\section{nOe measurements ${ }^{12}$}

The 1D ROESY experiments were obtained with a selective $180^{\circ}$ and non-seletive $90^{\circ}$ pulse. A mixing time of $0.5 \mathrm{~s}$ was used during the spin-lock. The selective pulse was generated by a waveform generator, which automatically attenuated the shape, power and pulse duration to achieve the required selectivity. The subtraction of the on- and off-resonance acquisition furnished the 1D ROESY experiment.

\section{Liposome preparation $^{13}$}

Liposome vesicles were obtained by evaporating stock chloroform solutions of egg phosphatidylcholine (EPC) under a flow of nitrogen. The samples were left under vacuum for $2 \mathrm{~h}$ to remove residual solvent. Then, the lipids were suspended in $0.4 \mathrm{~mol} \mathrm{~L}^{-1}$ phosphate/biphosphate buffer solution, $\mathrm{pH} 7.0$, producing large EPC multilamellar vesicles (MLV). The EPC (MLV) vesicles were extruded through Nucleopore ${ }^{\circledR}$ polycarbonate membranes having $0.4 \mu \mathrm{m}$ pore diameters (12 cycles), to form a suspension of $400 \mathrm{~nm}$ liposomes vesicles. The total lipid concentration was $5 \mathrm{mmol} \mathrm{L}^{-1}$.

\section{Agrobacterium tumefaciens NTL4(pZLR4)}

The bacteria was kept in Luria-Bertani (LB) medium supplemented with gentamicin $\left(50 \mu \mathrm{g} \mathrm{mL}^{-1}\right)$, under refrigeration $\left(5^{\circ} \mathrm{C}\right)$. It was inoculated in test tubes containing LB liquid medium $(2 \mathrm{~mL})$ and grown at $28^{\circ} \mathrm{C}$ for $24 \mathrm{~h}$. The cells were centrifuged and resuspended in $1 \mathrm{~mol} \mathrm{~L}^{-1}$ phosphate buffer, $\mathrm{pH} 7.0$, in $\mathrm{D}_{2} \mathrm{O}$ to reach $15 \mathrm{mg}$ of wet cells $/ \mathrm{mL}$, which were employed in the NMR STD experiments. This mutant was provided by Dr. Welington L. Araújo (originally from Dr. Stephen K. Farrand, University of Illinois). ${ }^{6}$

\section{Sample preparation}

Liposome experiment: An aqueous solution of HSL $\left(10 \mathrm{mmol} \mathrm{L}^{-1}\right) \mathbf{1}$ and $\beta$-CD $(10 \mathrm{mmol} \mathrm{L}-1)$ was stirred to solubilize the HSL. The water was evaporated under a flow of nitrogen. A liposome $\left(5 \mathrm{mmol} \mathrm{L}^{-1}\right)$ solution in pH 7.0 phosphate/biphosphate buffer using deuterated water $\left(\mathrm{D}_{2} \mathrm{O}, 99.9 \%\right)$ was added to the resulting residue (HSL/ $/$-CD).

Whole cells suspension experiments: $\mathrm{HSL}\left(10 \mathrm{mmol} \mathrm{L}^{-1}\right)$ 1 and $\beta-\mathrm{CD}\left(10 \mathrm{mmol} \mathrm{L}^{-1}\right)$ in aqueous solution were stirred at room temperature to dissolve the HSL, the water was evaporated under a flow of nitrogen. A phosphate/ biphosphate buffer solution in deuterated water $\left(\mathrm{D}_{2} \mathrm{O}\right.$, $99.9 \%)$ at $\mathrm{pH} 7.0(0.6 \mathrm{~mL})$ containing A. tumefaciens cells wet biomass $(16 \mathrm{mg})$ was added to the HSL/ $\beta-\mathrm{CD}$ residue.

\section{Synthesis of (S)-N-(3-oxo-octanoyl)-HSL $L^{14}$}

Meldrum acid derivative: A round-bottom flask $(50 \mathrm{~mL})$ containing dry dichloromethane $(20 \mathrm{~mL})$, hexanoic acid (2.0 mmol), 4-dimethylaminopyridine $(2.1 \mathrm{mmol})$, dicyclohexylcarbodiimide $(2.2 \mathrm{mmol})$ and Meldrum acid (2,2-dimethyl-1,3-dioxane-4,6-dione; $2.0 \mathrm{mmol}$ ) was stirred under nitrogen for $24 \mathrm{~h}$. The reaction mixture was filtered and the organic layer was evaporated under reduced pressure producing an yellow oil, to which ethyl acetate $(20 \mathrm{~mL})$ was added. This solution was washed with aqueous hydrochloric acid $\left(2 \mathrm{~mol} \mathrm{~L}{ }^{-1}, 3 \times 10 \mathrm{~mL}\right)$ distilled water $(1 \times 10 \mathrm{~mL})$ and dried over anhydrous magnesium sulfate. The organic layer was filtered and evaporated under reduced pressure (70 mg). The Meldrum acid derivative was used as quickly as possible in the next synthetic step.

(S)-N-(3-oxo-octanoyl)-HSL synthesis: To a roundbottom flask $(100 \mathrm{~mL})$ equipped with a refluxing condenser and magnetic stir bar, acetonitrile (22.5 mL, HPLC grade), the Meldrum acid derivative $(0.75 \mathrm{mmol})$, triethylamine $(1.2 \mathrm{mmol})$ and $(S)$ - $\alpha$-amino- $\gamma$-butyrolactone hydrobromide $(0.75 \mathrm{mmol})$ were added. The reaction mixture was stirred at room temperature for $2 \mathrm{~h}$ and then heated at reflux for $3 \mathrm{~h}$. The reaction medium was evaporated under reduced pressure, and the remaining white solid was dissolved in ethyl acetate and methanol $(20 / 5 \mathrm{~mL})$. The organic layer was washed with saturated aqueous sodium bicarbonate solution $(3 \times 10 \mathrm{~mL})$, potassium bisulfate $\left(1 \mathrm{~mol} \mathrm{~L}^{-1}\right.$ $3 \times 10 \mathrm{~mL})$, and saturated sodium chloride $(3 \times 10 \mathrm{~mL})$, dried over anhydrous magnesium sulfate, filtered and evaporated, yielding the crude product as a pale yellow solid that was further purified by silica gel column 
chromatography (12 g, Acros, 0.035-0.070 mm particle size; $2 \mathrm{~cm}$ diameter column) with hexane, dichloromethane and ethyl acetate, in increasing polarity, furnishing $70.0 \mathrm{mg}$ of $\mathbf{1}(28 \%$ overall yield $)$.

(S)-N-3-oxo-octanoyl-homoserine lactone 1 : $[\alpha]_{\mathrm{D}}{ }^{20}-17.0^{\circ}$ (c. $0.53 \mathrm{MeOH}) ; 94 \%$ ee [GC-FID (Chrompack chirasil)]; GC-MS (EI, $70 \mathrm{eV}$ ) m/z 241 (1\%), 224 (24), 185 (7), 143 (25), 102 (7), 99 (31), 56 (100); IR $v_{\max } / \mathrm{cm}^{-1}(\mathrm{KBr}) 3258$, 2934, 1777, 1716, 1646, 1546, 1173, 1019, 599; ${ }^{1} \mathrm{H}$ NMR (300.06 MHz, $\left.\mathrm{CDCl}_{3}, \mathrm{TMS}\right) \delta 0.89\left(\mathrm{t}, 3 \mathrm{H}, J 7.0 \mathrm{~Hz}, \mathrm{H}-8^{\prime}\right.$ ), 1.30 (m, 4H, H-6', H-7'), 1.59 (quintet, 2H, J 7.3 Hz, H-5'), 2.28 (m, 1H, H-4), 2.53 (t, 2H, J 7.3 Hz, H-4'), 2.75 (m, $1 \mathrm{H}, \mathrm{H}-4$ ), 3.47 (s, 2H, H-2'), 4.28 (ddd, 1H, J 11.0, 9.1 and $6.2 \mathrm{~Hz}, \mathrm{H}-5$ ), 4.47 (t, 1H, J $8.2 \mathrm{~Hz}, \mathrm{H}-3$ ), 4.60 (ddd, 1H, $J 11.3 ; 8.8$ and $6.2 \mathrm{~Hz}, \mathrm{H}-5), 7.70(\mathrm{~d}, \mathrm{NH}, J 5.1 \mathrm{~Hz}) ;{ }^{13} \mathrm{C}$ NMR (75.45 MHz, $\left.\mathrm{CDCl}_{3}, \mathrm{TMS}\right) \delta 13.8$ (C-8'), 22.32 (C7'), 23.0 (C-6'), 31.1 (C-5'), 29.8 (C-4), 43.8 (C-4'), 48.1 (C-2'), 49.0 (C-3), 65.8 (C-5), 166.4 (C-1'), 174.8 (C-2), 206.5 (C-3').

\section{Results and Discussion}

Substance 1 was synthesized according to a wellknown procedure shown in Scheme 1. ${ }^{14}$ The synthesis consisted of an initial carbon-carbon bond formation with hexanoic acid and 2,2-dimethyl-1,3-dioxane-4,6dione, furnishing a thermolabile Meldrum acid derivative, which was subsequently subjected to a thermal coupling/ elimination reaction with $(S)$ - $\alpha$-amino- $\gamma$-butyrolactone hydrobromide. The product $\mathbf{1}$ was obtained in moderate yield (28\% in two steps) and was fully characterized on the basis of spectroscopic data. The ${ }^{1} \mathrm{H}$ NMR chemical shifts of $\mathbf{1}$ in a deuterated water with $20 \%\left(\mathrm{CD}_{3}\right)_{2} \mathrm{SO}(600 \mu \mathrm{L})$ solvent system were fully assigned (Figure 1) taking into consideration previous assignments using 1D and 2D NMR experiments (gHSQC, gCOSY, gHMBC). ${ }^{15,16}$

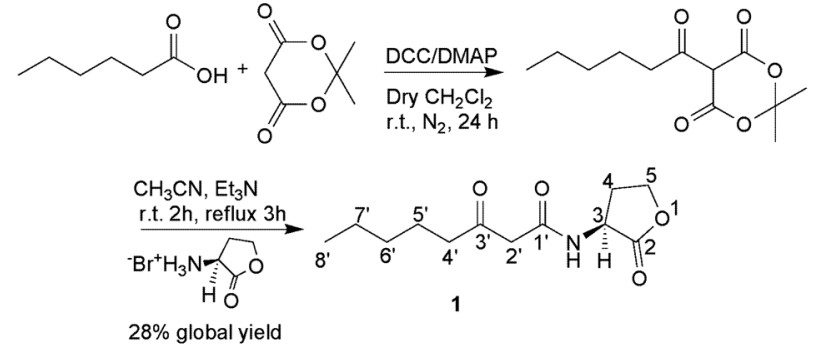

Scheme 1. Synthesis of substance $\mathbf{1}$.

Pure 1 was subsequently used in STD NMR experiments. Therefore, to gain further insight in the quorum-sensing phenomenon we have applied the STD experiment to a $\mathrm{D}_{2} \mathrm{O}$ solution with $1, \beta$-cyclodextrin and $A$. tumefaciens cells. It is important to indicate that this constitutes a case study, as $\mathbf{1}$ is the A.tumefaciens cognate signal. The STD experiment (Figure 2) revealed an epitope map between $\mathbf{1}$ and A. tumefaciens cells. The saturation transfer values were calculated by the individual signal intensities in the STD spectrum (ISTD) and in the reference NMR spectrum $\left(I_{\mathrm{o}}\right){ }^{17}$ Saturation transfer difference mapping indicated that $\mathbf{1}$ was bound to the cell, displaying different degrees of saturation for the individual protons. The acyl chain is an important anchoring point as observed by the high interaction percentages found for the H-8'-H-4' interval (Figure 2). At the lactone moiety the $\mathrm{H}-4$ displayed an important interaction (52\%) while $\mathrm{H}-5$ did not shown any interaction with cells in this experiment (Figure 2).

It should be mentioned that in the STD experiment with $1 / \beta-C D / A$. tumefaciens cells a $6 \%$ saturation transfer from A. tumefaciens to $\beta-\mathrm{CD}$ was observed while no saturation transfer was observed in the STD experiment with 1/ $\beta$-CD/EPC, shown below.

In all experiments, the solubilization of $\mathbf{1}$ in the $\mathrm{D}_{2} \mathrm{O} /\left(\mathrm{CD}_{3}\right)_{2} \mathrm{SO}$ solvent system required ultrasound and time consuming stirring, to reach the required concentrations



Figure 1. ${ }^{1} \mathrm{H}$ NMR spectrum $\left(499.89 \mathrm{MHz}, \mathrm{D}_{2} \mathrm{O} / \mathrm{DMSO}-d_{6} 20 \%\right.$ / ref. residual $\left.\mathrm{H}_{2} \mathrm{O} 4.70 \mathrm{ppm}\right)$ of $(S)$ - $N$-(3-oxo-octanoyl)-HSL $\left(10 \mathrm{mmol} \mathrm{L}{ }^{-1}\right)$ at $298 \mathrm{~K}$ and $\mathrm{pH}$ 7.0. 

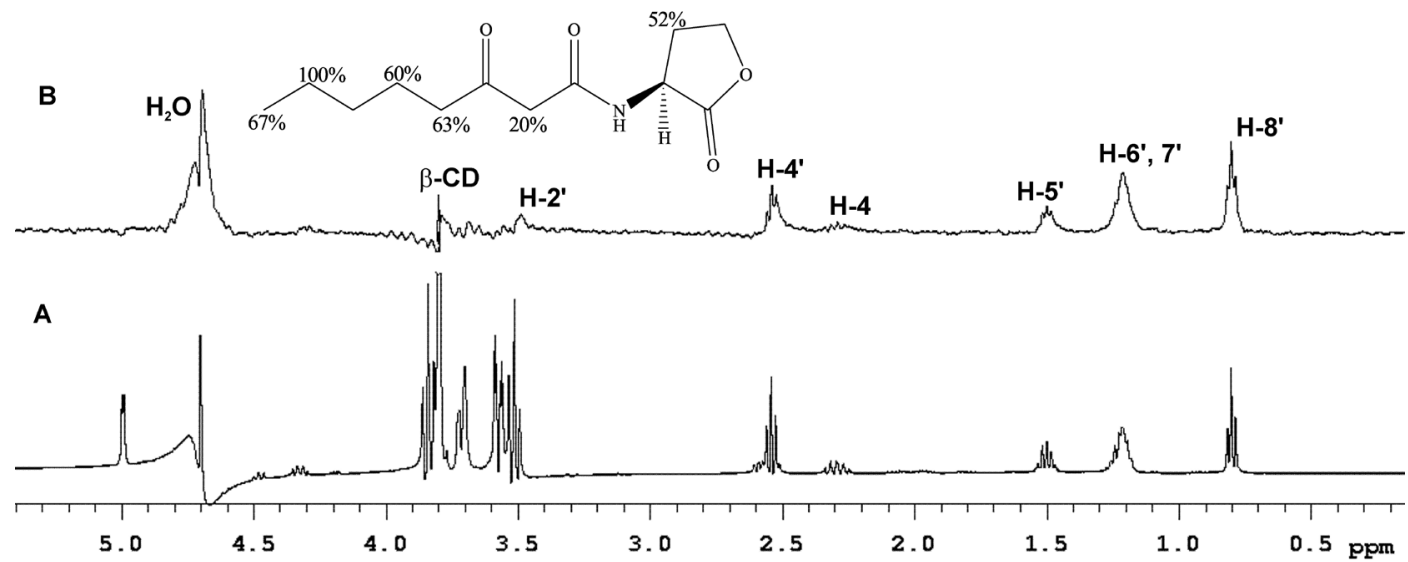

Figure 2. ${ }^{1} \mathrm{H}$ NMR spectra $\left(499.886 \mathrm{MHz}, \mathrm{D}_{2} \mathrm{O} /\right.$ ref. residual $\mathrm{H}_{2} \mathrm{O} 4.70 \mathrm{ppm}$ ) of the mixture of $\mathbf{1}, \beta-\mathrm{CD}$ and A. tumefaciens NTL4(pZLR4) cells. A) The off-resonance STD spectrum. B) The on-resonance STD spectrum. Top: (S)- $N$-(3-oxo-octanoyl)-HSL structure and the relative degree of saturation transfer of the individual protons normalized to $\mathrm{H}-7^{\prime}$.

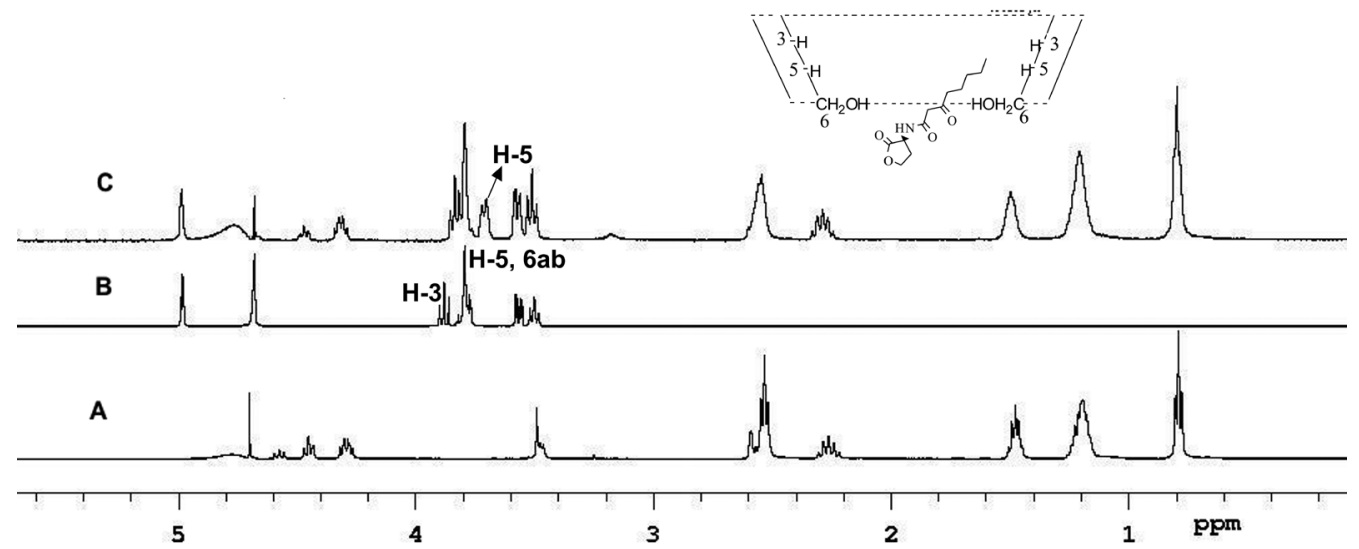

Figure 3. A) ${ }^{1} \mathrm{H}$ NMR spectrum (499.886 $\mathrm{MHz}, \mathrm{D}_{2} \mathrm{O} /$ ref. residual $\left.\mathrm{H}_{2} \mathrm{O} 4.70 \mathrm{ppm}\right)$ of $\mathbf{1}\left(10 \mathrm{mmol} \mathrm{L}^{-1}\right)$; $\left.\mathrm{B}\right) \beta-\mathrm{CD}\left(10 \mathrm{mmol} \mathrm{L} \mathrm{L}^{-1}\right)$ and $\left.\mathrm{C}\right)$ the mixture of $\mathbf{1}$ and $\beta-\mathrm{CD}$ at $298 \mathrm{~K}$ and $\mathrm{pH}$ 7.0. Top: suggested inclusion complex topology of $\mathbf{1} / \beta-\mathrm{CD}$.

for the NMR study. Therefore, the solubility of $\mathbf{1}$ was improved by encapsulation with $\beta$-cyclodextrin. Thus, the interactions of $\mathbf{1}$ with the cyclic sugar was studied in detail.

The topology of the complex between 1 and $\beta$-cyclodextrin was observed by ${ }^{1} \mathrm{H}$ NMR $1 \mathrm{D}$-ROESY spectrum using a signal enhancement (Overhauser effect) arising from dipolar couplings and cross relaxation between $\beta$-cyclodextrin $\mathrm{H}-5$ (at $3.71 \mathrm{ppm}$ ) and $\mathrm{H}-8^{\prime}(1.29 \%)$ and H-6', 7' $(1.82 \%)$ of $\mathbf{1}$. However no cross relaxation between 1 and $\beta-\mathrm{CD} \mathrm{H}-3$ (3.84 ppm) was detected. These enhancements indicated a complex formation, with a topology as shown in Figure 3, and hydrogen bonding between the 3-keto moiety of the lactone moiety of $\mathbf{1}$ and $\beta$-CD C-6 hydroxyl groups that might be responsible for this topology. Thus the acyl chain enters into the ring and interacts with H-5 $\beta$-cyclodextrin. This model is corroborated by the chemical shift changes observed for the $\beta$-cyclodextrin H-5 signal (from $3.81 \mathrm{ppm}$ to $3.71 \mathrm{ppm}$ ) in the presence of $\mathbf{1}$ (Figure 3 ).
Formation of EPC inclusion complexes-liposomes as membrane models

Egg phosphatidylcholine liposomes (EPC) have been extensively employed as membrane models. ${ }^{3,18}$ Based on our recent success in mapping the topology of drugliposomes complexes by STD-NMR, the interactions of $\mathbf{1}$ with liposomes were studied using this technique, aiming at a better understanding of the first binding events of $\mathbf{1}$ and the bacterial cells.

EPC $\left(5 \mathrm{mmol} \mathrm{L}^{-1}\right)$ addition to $1 / \beta-\mathrm{CD}$ in $\mathrm{D}_{2} \mathrm{O}$ buffered solution caused line broadening (Figure $4 \mathrm{~A}$ ) observed by ${ }^{1} \mathrm{H}$ NMR, indicating that both species (1 and EPC) were interacting with complex formation $(\mathrm{EPC}+\mathbf{1}=\mathrm{EPCHSL})$. The species in solution were in a fast dynamic equilibrium regime, therefore no signal duplication was observed. This preliminary binding evidence was further confirmed by the STD NMR experiment, revealing an epitope map between the macromolecule and $\mathbf{1}$. Once again, the acyl chain was crucial for the supramolecular interactions with 


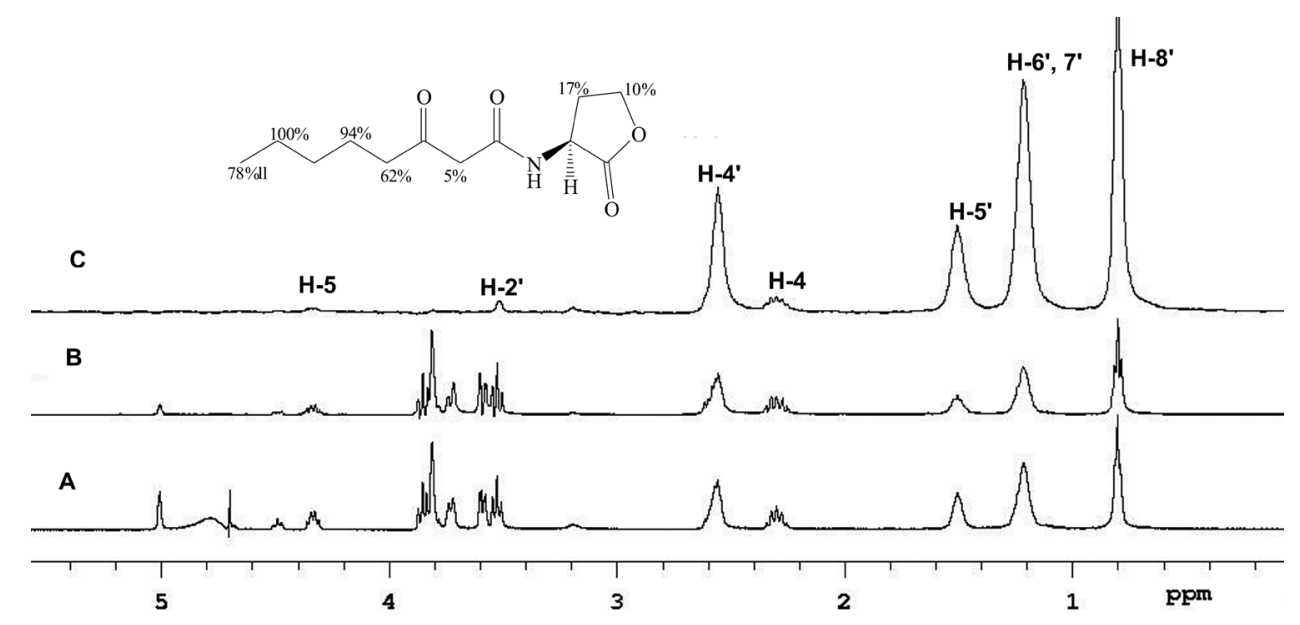

Figure 4. A) ${ }^{1} \mathrm{H}$ NMR spectra of the mixture of $1, \beta-\mathrm{CD}$ and EPC liposomes, $400 \mathrm{~nm}\left(499.886 \mathrm{MHz}, \mathrm{D}_{2} \mathrm{O} /\right.$ ref. residual $\left.\mathrm{H}_{2} \mathrm{O} 4.70 \mathrm{ppm}\right)$. B) The offresonance STD spectrum. C) The on-resonance STD spectrum. Top: (S)- $N$-(3-oxo-octanoyl)-HSL structure and the relative degree of saturation transfer of the individual protons normalized to $\mathrm{H}-7$ '

the hydrophobic liposome layer, as shown by the higher interaction coefficients displayed by the hydrogens in this moiety (Figure 4). This result is very similar to the epitope map observed for $\mathbf{1}$ and A. tumefaciens cells, indicating that the first binding events of the molecule with the cell occur at the membrane level. Therefore, the high affinity of $\mathbf{1}$ for the cell membrane corroborates the diffusion mechanism hypothesis, minimizing the possibility of a carrier protein or even a permease action during the metabolite intake.

Since quorum-sensing is a widespread phenomenon in pathogenic bacteria, the development of signal antagonists have undergone significant evolution in recent years. ${ }^{19}$ The main goals are to block pathogenic phenotype expression or rather to reduce the bacterial resistance to common antibiotics, as for example in biofilm weakening. The approach consists of synthesizing substances that compete with the natural signal for the receptor protein active site. The antagonist-protein complex should display a tridimensional conformation distinct from that observed for the signal complex, changing the complex stability and the supramolecular affinity of the complex with the DNA operator sites and thereafter reducing or blocking gene expression. ${ }^{20}$ Thus, much attention has been focused on the signalling molecule-protein binding, while the first binding events at the membrane level have been somewhat neglected. Therefore, the epitope maps provided herein may be important for antagonist design, to create molecules with improved cell affinity and competition tasks in comparison with natural signals, mainly at the cross-membrane stage. Equally, the STD NMR protocol depicted herein may also be an important tool for membrane interaction analyses of synthesized antagonists. Furthermore, the usefulness of liposomes as membrane models for quorum-sensing studies was checked through direct comparison with a real cell-based experiment.

\section{Conclusions}

This work revealed cell and quorum sensing signalling molecule interactions though the epitope map of 3-oxooctanoyl-HSL with A. tumefaciens NTL4(pZLR4) cells by a pioneering application of the STD-NMR technique to this system. It was also demonstrated that liposomes are wellsuited models for acyl-HSLs/membrane studies, and can constitute an important tool for a better understanding of the quorum-sensing "machinery". Due to the importance of A. tumefaciens in agriculture and genetic research, we hope these data and procedures also constitute an important aid for structure-activity relationship studies aiming to produce more efficient quorum-sensing inhibitors, since synthetic antagonists could also interact with the cellular membrane. Further work is being carried out in our group to investigate if STD can detect which type of acyl-homoserine lactone molecule is better suited to promote reponse in a specific bacterium, mainly at the cross-membrane level.

\section{Acknowledgments}

The group is grateful to FAPESP (A.M.P. 05/02934-4; P.L.R.C., 07/52389-8) and CAPES (L.F.C. 141841/2006-0) for financial support and scholarships. We are also indebted to Dr. Carol H. Collins (Unicamp) for manuscript revision.

\section{References}

1. Whitehead, N. A.; Barnard, A. M. L.; Slater, H.; Simpson, N. J. L.; Salmond, G. P. C.; FEMS Microbiol. Rev. 2001, 25, 365. 
2. Pearson, J. P.; Van Delden, C.; Iglewski, B. H.; J. Bacteriol. 1999, 181, 1203.

3. Park, J.; Breast Cancer Res. 2002, 4, 95.

4. Zhang, L.; Murphy, P. J.; Kerr, A.; Tate, M. E.; Nature 1993, $362,446$.

5. Qin, Y.; Luo, Z. Q.; Smyth, A. J.; Gao, P.; Beck, V. B. S.; Farrand, S. K.; EMBO J. 2000, 19, 5212.

6. Cha, C.; Gao, P.; Chen, Y-C.; Shaw, P. D.; Farrand, S. K.; Mol. Plant-Microbe Interact. 1998, 11, 1119.

7. Zhang, R. G.; Pappas, T.; Brace, J. L.; Miller, P. C.; Oulmassov, T.; Molyneaux, J. M.; Anderson, J. C.; Bashkin, J. K.; Winans, S. C.; Joachimiak, A.; Nature 2002, 417, 971.

8. Cabeça, L. F.; Fernandes, S. A.; de Paula, E.; Marsaioli, A. J.; Magn. Reson. Chem. 2008, 46, 832.

9. Carlomagno, T.; Annu. Rev. Biophys. Biomol. Struct. 2005, 34, 245.

10. Klein, J.; Meinecke, R.; Mayer, M.; Meyer, B.; J. Am. Chem. Soc. 1999, 121, 5336.

11. Mayer, M.; Meyer, B.; Angew. Chem., Int. Ed. 1999, 38, 1784.

12. Mo, H.; Pochapsky, T. C.; Prog. Nucl. Magn. Reson. Spectrosc. 1997, 30, 1 .

13. Cereda, C. M. S.; Araújo, D. R.; Brunetto, G. B.; de Paula, E.; J. Pharm. Pharmacol. Sci. 2004, 7, 235.
14. Chhabra, S. R.; Harty, C.; Hooi, D. S. W.; Daykin, M.; Williams, P.; Telford, G.; Pritchard, D. I.; Bycroft, B. W.; J. Med. Chem. 2003, 46, 97.

15. Pomini, A. M.; Araújo, W. L.; Marsaioli, A. J.; J. Chem. Ecol. 2006, 32, 1769.

16. Pomini, A. M.; Paccola-Meirelles, L. D.; Marsaioli, A. J.; J. Agric. Food Chem. 2007, 55, 1200.

17. Meyer, B.; Peters, T.; Angew. Chem., Int. Ed. 2003, 42, 864.

18. Fraceto, L. F.; Pinto, L. M. A.; Franzoni, L.; Braga, A. A. C.; Spisni, A.; Schreier, S.; de Paula, E.; Biophys. Chem. 2002, 99 , 229.

19. Smith, K. M.; Bu, Y.; Suga, H.; Chem. Biol. 2003, 10, 81.

20. Manefield, M.; Rasmussen, T. B.; Henzter, M.; Andersen, J. B.; Steinberg, P.; Kjelleberg, S.; Givskov, M.; Microbiology 2002, $148,1119$.

Submitted: July 14, 2010 Published online: January 13, 2011

FAPESP has sponsored the publication of this article. 